\title{
Morphology and distribution of the cave knifefish Eigenmannia vicentespelaea Triques, 1996 (Gymnotiformes: Sternopygidae) from Central Brazil, with an expanded diagnosis and comments on subterranean evolution
}

\author{
Maria Elina Bichuette and Eleonora Trajano
}

\begin{abstract}
We present herein data on morphology and distribution of the cave knifefish Eigenmannia vicentespelaea Triques, 1996, from the São Domingos karst area, Central Brazil, comparing it to the epigean (surface) species, Eigenmannia sp., found in the same area (but not syntopic with E. vicentespelaea) and also with congeners from other localities. Collecting sites comprising epigean and subterranean stream reaches in São Domingos were sampled during the dry seasons of 1999, 2000, and 2001 using several methods. Preserved specimens of E. vicentespelaea ( $\mathrm{n}=25$, including holotype and paratype) and of Eigenmannia $\mathrm{sp}$. $(\mathrm{n}=15)$ were compared with focus on morphometric characters, body pigmentation and eye condition. A combination of characters separates E. vicentespelaea from Eigenmannia sp. and other congeners: the length from the tip of the snout to the posterior of the anal fin base, ocular diameter: head length and pre-anal distance: head length proportions, and body pigmentation. A wider morphometric variation in E. vicentespelaea is described than that reported in the original description (based on two specimens).
\end{abstract}

São apresentados dados sobre a morfologia e distribuição do peixe-elétrico cavernícola Eigenmannia vicentespelaea Triques, 1996, da área cárstica de São Domingos, Brasil Central, comparando-o com a espécie epígea da mesma área, Eigenmannia sp. e congêneres de outras localidades. Coletas de exemplares foram feitas em trechos epígeos e subterrâneos de rios durante as estações secas de 1999, 2000 e 2001, utilizando-se diferentes métodos de coleta. Espécimes preservados de E. vicentespelaea $(\mathrm{n}=25$, incluindo holótipo e parátipo) e Eigenmannia $\mathrm{sp}$. $(\mathrm{n}=15)$ foram comparados em relação a caracteres morfométricos, de pigmentação do corpo e da condição dos olhos. Uma combinação de caracteres separa E. vicentespelaea de Eigenmannia sp. e de outros congêneres: o comprimento da extremidade do focinho até a porção posterior da base da nadadeira anal, as proporções diâmetro ocular:comprimento da cabeça e distância pré-anal:comprimento da cabeça, e pigmentação do corpo. É descrita uma ampla variação dos caracteres morfométricos em E. vicentespelaea, comparando-se com a descrição original (baseada em dois espécimes).

Key words: Morphometric data, electric fishes, cave environment, São Domingos karst area.

\section{Introduction}

Electric fishes of the Order Gymnotiformes are an important component of the night-active ichthyofauna in South and Central America, corresponding to a monophyletic group based, among other characters, on the ability of producing and detecting weak electric fields (Alves-Gomes et al., 1995; Albert \& Campos-da-Paz, 1998; Albert, 2001). These fishes are distributed between $35^{\circ} \mathrm{S}$, in Argentina, and $18^{\circ} \mathrm{N}$, in Mexico (Eigenmann \& Allen, 1942; Bullock et al., 1979; Mago-Leccia, 1994), with some genera occurring almost exclusively in deep waters of the Amazon basin. The adaptations related to their predomi- nantly nocturnal activity favor the colonization of totally dark habitats such as those in the subterranean realm (defined as the network of interconnected subsoil spaces, with variable sizes, filled with water or air and characterized by permanent darkness- sensu Juberthie, 2000).

According to Albert \& Campos-da-Paz (1998) and Albert (2001; 2003), Sternopygidae Cope, 1871 is also a monophyletic group. The monophyly of its 23 recognized species - distributed in the genera $\dagger$ Ellisella, Sternopygus, Archolaemus, Rhabdolichops, Eigenmannia, and Distocyclus - is supported by 14 anatomical and physiological characters. However, AlvesGomes et al. (1995), analyzing mitochondrial sequence data,

Departamento de Zoologia, Instituto de Biociências da USP, Caixa Postal 11.461, 05422-970 São Paulo, SP, Brazil. bichuette@uol.com.br; etrajano@usp.br 
morphological and electrophysiological characters, suggested that Sternopygidae is not a natural group and proposed a new family, Eigenmanniidae, comprising the genera Rhabdolichops $+($ Eigenmannia + Distocyclus $)$. Nevertheless, the monophyly of Eigenmannia Jordan \& Evermann, 1896 was not demonstrated yet and its taxonomy remains confused (Mago-Leccia, 1978; Lundberg \& Mago-Leccia, 1986; Albert, 2001).

The only known troglobitic gymnotiform is $E$. vicentespelaea Triques, 1996, from the São Domingos karst area, upper Tocantins River basin, in Central Brazil (troglobites are defined as species restricted to subterranean habitats, usually showing specializations related to the evolution in isolation in this environment - troglomorphisms sensu Christiansen, $1962)$. This species was included in the $E$. virescens speciesgroup (sensu Albert, 2001), which comprises four species (E. virescens, E. trilineata, E. vicentespelaea, and an undescribed species) sharing the following character states: two or three longitudinal lines on either side of the body; lateral valvula cerebellum large; and anterior intermuscular highly branched.

Triques (1996) based the description of $E$. vicentespelaea on two specimens collected in 1978 in São Vicente I Cave. The species diagnosis was based in the proportion of the ocular diameter in relation to the head length. This character has also been used to separate the epigean (surface) species, $E$. macrops, E. humboldtii and E. virescens, from Venezuela (Mago-Leccia, 1978), and also Sternarchorhynchus species from Brazil (Campos-da-Paz, 1997).

During a study on the epigean and subterranean ichthyofauna from São Domingos karst area, including the ecology and behavior of Eigenmannia spp. (Bichuette, 2003; Bichuette $\&$ Trajano, 2003), specimens of the cave E. vicentespelaea and an epigean species were collected, allowing a comparative study of their external morphology. The identification of the epigean species equivocal became because some character states (overlapping of OD:HL and SNL:HL proportions - R. Campos-daPaz, pers. comm.) indicated that it would belong to the E. macrops species-group (sensu Albert, 2001), representing a new geographical record for this group (upper Tocantins River basin). However, the inclusion of the epigean species in the E. macrops species-group is doubtful since other character states, such as three longitudinal lines along the body, characteristic of the $E$. virescens species-group, are present in this species. For this reason, this epigean species from Domingos karst area is herein referred as Eigenmannia sp.

Preliminary observations on the large intrapopulational variability regarding eyes and body pigmentation in $E$. vicentespelaea, combined with the morphological similarity between the two Eigenmannia species from São Domingos karst area, raised some doubts about the diagnosis of $E$. vicentespelaea.

We present herein morphometric and distributional data on E. vicentespelaea, comparing it to the epigean species Eigenmannia sp. from the same area and congeners from other regions. An expanded diagnosis is proposed for the former, and the evolution in the subterranean environment is discussed.

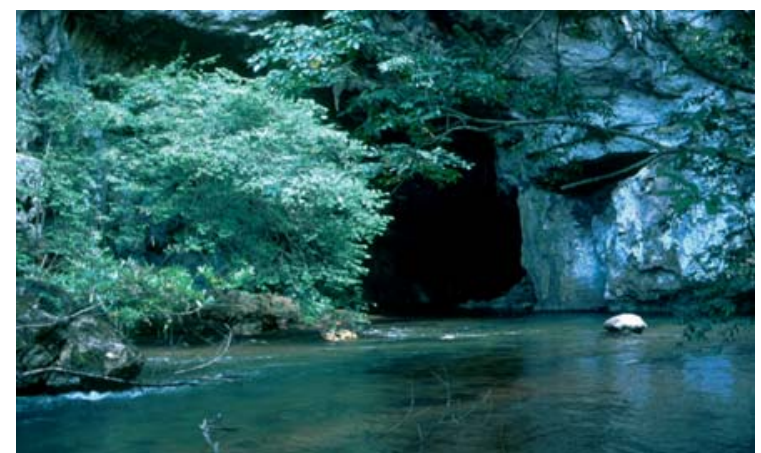

Fig. 1. Sinkhole of São Vicente Cave System, São Domingos karst area, Goiás State, Central Brazil - type locality of Eigenmannia vicentespelaea Triques, 1996. Photo: E. M. Bichuette.

Study area. During the present study, specimens of $E$. vicentespelaea were found in the São Vicente I and São Vicente II caves, and specimens of Eigenmannia sp. in the Rio da Lapa and subterranean stream reaches of the São Mateus and Angélica caves. These localities are within the limits of the Terra Ronca State Park $\left(13^{\circ} 30^{\prime}-13^{\circ} 50^{\prime}\right.$ S, $46^{\circ} 0^{\prime}$ $46^{\circ} 30^{\prime} \mathrm{W}$ ), in São Domingos County, eastern State of Goiás, Central Brazil. The area lies in the Cerrado (the savannah-like Brazilian vegetation) phytogeographic domain (Ab'Saber, 1977), presenting a tropical semi-humid climate with 4-5 dry mo/yr (Nimer, 1979). São Domingos is a carbonate karst area characterized by the presence of continuous limestone outcrops belonging to the Bambuí Group and is crossed by several parallel streams running westward to join the Paranã River, a tributary of the upper Tocantins River, Amazon basin. After an epigean reach, each major stream enters into a cave through a sinkhole (Fig. 1), crossing hundreds to thousands of meters through subterranean conduits, and emerging to the surface through resurgence.

Eigenmannia vicentespelaea coexists with epigean fishes in the São Vicente I Cave (a siluriform, Pseudocetopsis plumbeus) and São Vicente II Cave (a siluriform, Spatuloricaria sp. and four gymnotiforms, Sternopygus sp., Sternarchorhynchus mesensis, Archolaemus blax, and Porotergus sp.). The epigean Eigenmannia species coexists, in the Rio da Lapa, with characiforms (Brycon undescribed species, Characidium sp., and Creagrutus britski) and siluriforms (Pseudocetopsis plumbeus, Aspidoras poecilus, Parotocinclus undescribed species, Hypostomus sp., Ancistrus sp., Phenachorhamdia tenebrosa, and Imparfinis hollandi) (Bichuette \& Trajano, 2003).

\section{Materials and Methods}

For the comparative study of the external morphology and morphometry of Eigenmannia species, different localities comprising both epigean and subterranean streams were sampled during the dry seasons of 1999, 2000, and 2001 using different collecting methods (e.g., hand-nets during snorkeling, electrofishing, and nets installed in the marginal vegetation of the epigean streams). The collected specimens were preserved 
in formalin and transferred to $70 \%$ alcohol for studies in the laboratory, where they were measured straight-line under a stereomicroscope with a dial caliper, $0.1 \mathrm{~mm}$ precision, on the left side. Measurements followed Mago-Leccia (1978), Triques (1996), and Campos-da-Paz (1997, 2000): LEA, length from the tip of the snout to the posterior of the anal fin base; HL, head length; SNL, snout length; OD, ocular diameter; PF, length of the pectoral fin; PPD, pre-pectoral distance; DSA, snout-anus distance; PAD, pre-anal distance. The following proportions were calculated (expressed in \%): OD:HL, SNL:HL, PF:HL, HL:LEA, DSA:LEA and PAD:LEA. The degree of body pigmentation in preserved animals was categorized into two classes: evident pigmentation $(\mathrm{P})$ with some coloration pattern (evident longitudinal stripes), and reduced pigmentation with faint longitudinal stripes -(RE). Three individuals of each species were cleared and stained (C\&S) following the Taylor \& Van Dyke (1985) method. All specimens were deposited in the ichthyological collection of the Museu de Zoologia da Universidade de São Paulo (MZUSP), Brazil.

In total, 25 specimens of $E$. vicentespelaea from the São Vicente cave system and 15 specimens of Eigenmannia sp. from the epigean reach of Rio da Lapa (11) as well as subterranean reaches of the São Mateus (2) and Angélica (2) streams were examined. The measurements of the holotype and paratype of E. vicentespelaea (Triques, 1996) were also included in the graphical and statistical analyses. In addition, morphometric data on other Eigenmannia species were obtained from literature (Mago-Leccia, 1978, 1994): E. humboldtii (Steindachner, 1878) $(\mathrm{n}=18)$, E. virescens (Valenciennes, 1842) $(\mathrm{n}=14)$, E. macrops (Boulenger, 1897) $(\mathrm{n}=12)$, and E. nigra Mago-Leccia, 1994 ( $\mathrm{n}=7$ ).

In order to test possible differences among the data set relative to the body size and the proportions between OD:HL and PAD:HL, non-parametric tests (Mann-Whitney and Wilcoxon) and ANOVA analysis (with a posteriori Dunn's test) were applied. The Spearman correlation test was applied in the comparison between LEA and OD values (Zar, 1996). Before each test, data were tested for homogeneity of variance (homoscedasticity) and normality. All analysis were made using Sigma Stat software (version 2.0), with á=0.05.

\section{Results}

Eigenmannia sp. was so far recorded in the epigean reach of Rio da Lapa, from the Terra Ronca Cave entrance (sinkhole of the stream - $13^{\circ} 44^{\prime} 00^{\prime \prime} \mathrm{S} 46^{\circ} 21^{\prime} 30^{\prime \prime} \mathrm{W}$ ) to about $100 \mathrm{~m}$ upstream, and in subterranean stream reaches of the Angélica $\left(13^{\circ} 31^{\prime} 24^{\prime \prime S} 46^{\circ} 23^{\prime} 20^{\prime \prime} \mathrm{W}\right)$ and São Mateus III (13º $46^{\prime} 05.5^{\prime \prime S}$ $\left.46^{\circ} 22^{\prime} 00^{\prime \prime} \mathrm{W}\right)$ caves. The latter were always observed near the cave stream resurgences (where a subterranean stream reaches the surface). Apparently, the cave species, E. vicentespelaea, recorded only in caves of the São Vicente cave system $\left(13^{\circ} 35^{\prime} 30^{\prime \prime} \mathrm{S} 46^{\circ} 21^{\prime} 00^{\prime \prime} \mathrm{W}\right.$, at the stream sinkhole in the São Vicente I Cave), has no contact with Eigenmannia sp., since the latter has not been found in epigean reaches of the São Vicente stream.

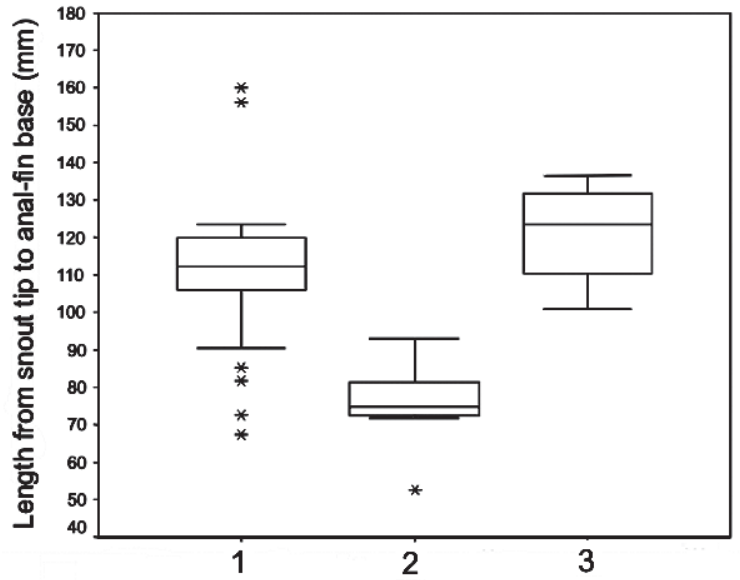

Fig. 2. Length (LEA) medians (horizontal bars), standard deviations and confidence intervals for Eigenmannia vicentespelaea $(\mathrm{n}=25)$ and Eigenmannia $\mathrm{sp} .(\mathrm{n}=15)$ from São Domingos karst area, Central Brazil. *outliers; 1, E. vicentespelaea; 2, Eigenmannia sp. collected in epigean river; 3, Eigenmannia sp. collected in subterranean stream reaches.

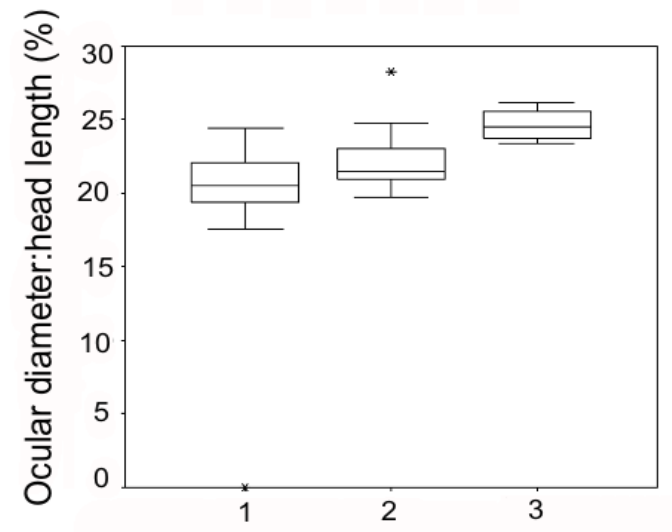

Fig. 3. Ocular diameter:head length proportions, standard deviations and confidence intervals for Eigenmannia vicentespelaea $(\mathrm{n}=25)$ and Eigenmannia $\mathrm{sp} .(\mathrm{n}=15)$ from São Domingos karst area, Central Brazil. *outliers; 1, E. vicentespelaea; 2, Eigenmannia sp. collected in epigean river; 3 , Eigenmannia sp. collected in subterranean stream reaches; horizontal bars, medians.

Morphometric data relative to the two studied species of Eigenmannia are shown in Table 1 (data from holotype and paratype not included) and a summary of differences between Eigenmannia species is presented in Table 2. Individuals smaller than $70 \mathrm{~mm}$ LEA (E. vicentespelaea) and $50 \mathrm{~mm}$ (Eigenmannia sp.) were not found. The LEA medians and the proportions between OD and HL and between OD and LEA, in both $E$. vicentespelaea and Eigenmannia sp., are shown in Figs. 2 and 3, respectively. The regression between OD and LEA in E. vicentespelaea is shown in Figure 4.

On average, E. vicentespelaea specimens showed body length measurements significantly larger than the examined 
Table 1. Morphometric data for the cave knifefish, $E$. vicentespelaea $(\mathrm{n}=23)$ and epigean knifefish, Eigenmannia sp. ( $\mathrm{n}=15)$, from São Domingos karst area, Goiás State, Central Brazil. Measurements expressed in $\mathrm{mm}$ and proportions in percentage. $\mathrm{Sd}$, standard deviation; $\mathrm{P}$, pigmented individual; $\mathrm{RE}$, reduced pigmentation.

\begin{tabular}{lcccccc}
\hline & \multicolumn{2}{c}{ E. vicentespelaea } & \multicolumn{3}{c}{ Eigenmannia sp. } \\
& Range & Mean & Sd & Range & Mean & Sd \\
\hline LEA & $67.6-164.5$ & 111.8 & 24.73 & $52.6-136.4$ & 84.5 & 26.48 \\
HL & $8.9-18.5$ & 13.3 & 2.19 & $8.4-16.9$ & 12.2 & 2.59 \\
SNL & $2.6-6.0$ & 4.1 & 0.83 & $2.0-5.7$ & 3.6 & 0.93 \\
OD & $0-1.9$ & 1.3 & 0.39 & $1.2-2.5$ & 1.7 & 0.32 \\
PF & $6.3-14.4$ & 10.3 & 1.87 & $6.1-12.2$ & 8.7 & 1.96 \\
PPD & $9.3-20.7$ & 14.6 & 2.60 & $8.9-17.4$ & 12.8 & 2.56 \\
DSA & $4.7-9.7$ & 7.9 & 1.14 & $5.3-9.9$ & 6.9 & 1.40 \\
PAD & $12.7-23.7$ & 19.0 & 2.79 & $7.6-25.7$ & 16.2 & 5.04 \\
HL:LEA & $10.6-15.0$ & 12.1 & 0.97 & $12.0-16.7$ & 14.9 & 1.98 \\
SNL:HL & $27.7-36.1$ & 31.0 & 2.03 & $23.8-36.4$ & 29.4 & 3.15 \\
OD:HL & $0-24.4$ & 19.8 & 4.71 & $19.7-28.3$ & 23.0 & 2.38 \\
PF:HL & $65.2-92.9$ & 76.2 & 6.49 & $65.8-86.8$ & 73.0 & 5.64 \\
DSA:LEA & $5.9-9.6$ & 7.3 & 0.93 & $6.4-11.8$ & 8.5 & 1.45 \\
PAD:LEA & $14.3-24.4$ & 17.3 & 2.14 & $10.6-26.4$ & 19.0 & 3.78 \\
PAD:HL & $128-171$ & 143.6 & 12.02 & $77-157$ & 128.4 & 17.57 \\
Pigments & $91.3 \%$ RE & & & $13.3 \%$ RE & & \\
(\%) & $8.7 \%$ P & & & $86.7 \% \mathbf{P}$ & & \\
\hline
\end{tabular}

specimens of Eigenmannia sp. $(\mathrm{T}=160.0, \mathrm{p}=0.029)$ (Fig. 2$)$. Only Eigenmannia sp. specimens captured in the subterranean reaches of the São Mateus III and Angélica streams overlapped in size with those of $E$. vicentespelaea. Compared to other Eigenmannia species, E. vicentespelaea showed body lengths significantly smaller than $E$. humboldtii $(\mathrm{T}=24.0$; $\mathrm{p}=0.000)$ and $E$. nigra $(\mathrm{W}=325.0 ; \mathrm{p}=0.000)($ Table 2$)$.

The OD:HL proportions varied between 17.6 and $24.4 \%$ in most examined specimens of $E$. vicentespelaea (with one case of individual with no externally visible eyes - Fig. 5), and between 19.7 and $28.3 \%$ in Eigenmannia sp. OD:HL proportions in E. vicentespelaea are significantly smaller than the observed for Eigenmannia sp. $(\mathrm{T}=-418.0 ; \mathrm{p}=0.002)$. In addition, the eye size variation herein recorded for $E$.

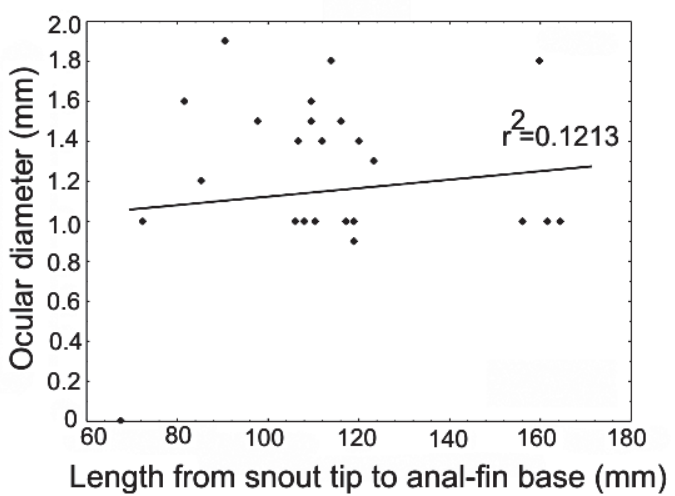

Fig. 4. Regression between OD and LEA in Eigenmannia vicentespelaea $(\mathrm{n}=25)$.

vicentespelaea is much wider than the proposed as diagnostic for this species, between 8.2 and $8.8 \%$ (Triques, 1996).

In relation to the PAD:HL proportions, Mann-Whitney and ANOVA analysis showed that $E$. vicentespelaea presents values significantly higher than Eigenmannia $\mathrm{sp} .(\mathrm{T}=46.0 ; \mathrm{p}=0.001)$, E. humboldtii $(\mathrm{Q}=6.243 ; \mathrm{p}<0.05)$, E. virescens $(\mathrm{Q}=3.326 ; \mathrm{p}<0.05)$ and E. macrops $(\mathrm{Q}=3.962 ; \mathrm{p}<0.05)($ Table 2$)$. At the size range recorded for $E$. vicentespelaea, there was no significant correlation between OD and LEA ( $\mathrm{r}=0.0752 ; \mathrm{p}=0.725)$ (Fig. 4).

Regarding coloration, specimens of $E$. vicentespelaea with reduced pigmentation - RE (91.3\% of the sample) presented a translucent aspect when alive (Fig. 6). Only $8.7 \%$ of the examined E. vicentespelaea specimens showed body pigmentation similar to that of Eigenmannia sp. When preserved in alcohol, specimens of E. vicentespelaea showed a pale aspect, with no visible longitudinal stripes (Figs. 5a-b).

Based on the characters presently analyzed, we propose a combination of characters separating $E$. vicentespelaea from its congeners: LEA, OD:HL and PAD:HL proportions and body pigmentation.

Table 2. Compared data of Eigenmannia species from South and Central America. * Data from Mago-Leccia $(1978,1994)$ and Albert (2001, 2003).

\begin{tabular}{|c|c|c|c|c|c|c|}
\hline & E. vicentespelaea & Eigenmannia sp. & E. humboldtii* & E. virescens ${ }^{*}$ & E. macrops* & E. nigra* \\
\hline LEA range & $67.6-164.5 \mathrm{~mm}$ & $52.6-136.4 \mathrm{~mm}$ & $125.5-255.0 \mathrm{~mm}$ & $79.4-194.2 \mathrm{~mm}$ & $73.9-136.5 \mathrm{~mm}$ & $172.1-334.0 \mathrm{~mm}$ \\
\hline HL range & $8.9-18.5 \mathrm{~mm}$ & $8.4-16.9 \mathrm{~mm}$ & $17.2-33.8 \mathrm{~mm}$ & $10.7-25.0 \mathrm{~mm}$ & $11.1-19.9 \mathrm{~mm}$ & $25.0-44.7 \mathrm{~mm}$ \\
\hline OD range & $0-1.9 \mathrm{~mm}$ & $1.2-2.5 \mathrm{~mm}$ & $3.0-5.3 \mathrm{~mm}$ & $2.3-4.9 \mathrm{~mm}$ & $2.8-4.3 \mathrm{~mm}$ & $4.8-8.5 \mathrm{~mm}$ \\
\hline OD:HL range & $0-24.4 \%$ & $19.7-28.3 \%$ & $15.0-22.0 \%$ & $14.0-22.0 \%$ & $21.0 \%-31.0 \%$ & $17.3-19.2 \%$ \\
\hline PAD:HL range & $128-171 \%$ & $77-157 \%$ & $94-113 \%$ & $107-158 \%$ & $74-134 \%$ & $158.4-194.1 \%$ \\
\hline $\begin{array}{l}\text { Body } \\
\text { pigmentation }\end{array}$ & Translucent aspect & $\begin{array}{l}\text { Three longitudinal } \\
\text { stripes, overlapping } \\
\text { of OD:HL and } \\
\text { SNL:HL proportions }\end{array}$ & $\begin{array}{l}\text { Black spots along the } \\
\text { body and head }\end{array}$ & $\begin{array}{l}\text { Two to three } \\
\text { longitudinal stripes } \\
\text { on either side of the } \\
\text { body }\end{array}$ & $\begin{array}{l}\text { Overlapping of } \\
\text { OD:HL and SNL:HL } \\
\text { proportions }\end{array}$ & Black coloration \\
\hline $\begin{array}{l}\text { Geographic } \\
\text { distribution }\end{array}$ & $\begin{array}{l}\text { Central Brazil: } \\
\text { Tocantins River } \\
\text { basin (São Vicente } \\
\text { cave system) }\end{array}$ & $\begin{array}{l}\text { Central Brazil: } \\
\text { Tocantins River } \\
\text { basin (rio da Lapa, } \\
\text { subterranean stream } \\
\text { reaches of Angélica } \\
\text { and São Mateus III } \\
\text { caves) }\end{array}$ & $\begin{array}{l}\text { Northern South } \\
\text { America: Brazil, } \\
\text { Colombia and } \\
\text { Venezuela }\end{array}$ & $\begin{array}{l}\text { > From Orinoco to La } \\
\text { Plata River basins }\end{array}$ & Brazil and Guyana & $\begin{array}{l}\text { Northern South } \\
\text { America: Brazil, } \\
\text { Colombia, Guyana } \\
\text { and Venezuela }\end{array}$ \\
\hline
\end{tabular}




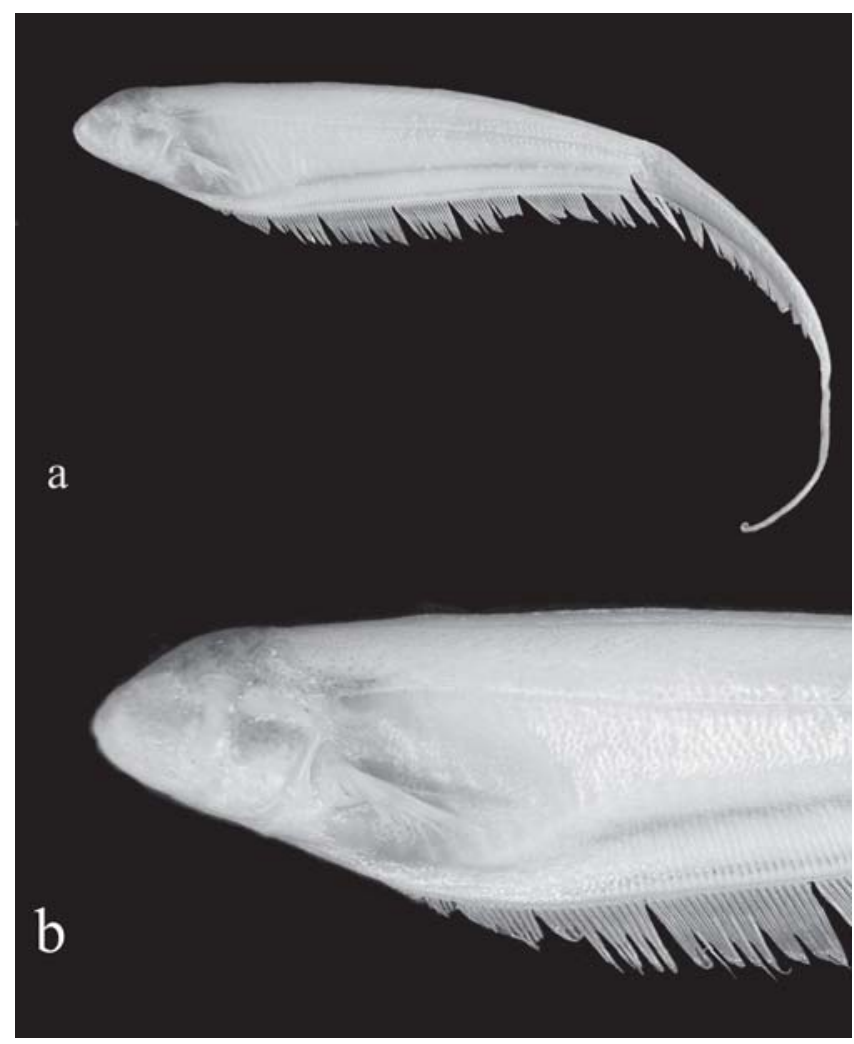

Fig. 5. Preserved specimen of Eigenmannia vicentespelaea with no visible eyes and pale aspect (LEA: $67.6 \mathrm{~mm}$ ). a. Entire individual. Scale bar, $10 \mathrm{~mm}$; $\mathbf{b}$. Detail of head with no visible eyes. Scale bar, $5 \mathrm{~mm}$. Photos: M. E. Bichuette.

Expanded diagnosis. Eigenmannia vicentespelaea differs from the epigean Eigenmannia sp. from São Domingos karst area and other epigean congeners, by the following combination of characters: significantly reduced eyes, with ocular diameter usually between 17.6 and $24.4 \%$ of head length, rarely with no externally visible eyes (OD:HL 19.7 to $28.3 \%$ in Eigenmannia sp.); body pigmentation reduced, with a translucent aspect when alive; average body lengths significantly larger than that recorded for Eigenmannia sp. and smaller than that recorded for $E$. humboldtii and $E$. nigra. PAD:HL proportions significantly larger than in E. humboldtii, E. virescens and E. macrops.

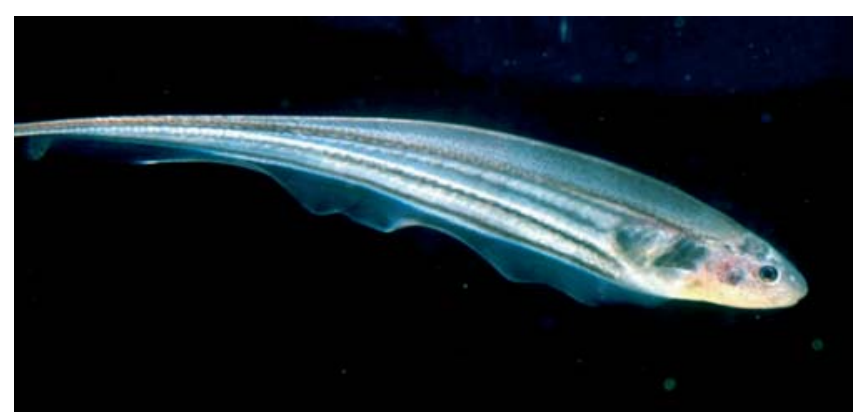

Fig 6. Living specimen of Eigenmannia vicentespelaea with relatively well developed eyes and translucent aspect. Note the three longitudinal stripes (LEA: $121.9 \mathrm{~mm}$ ). Photo: José Sabino.

\section{Discussion}

In view of the confused taxonomy and the disputed monophyly of the genus Eigenmannia, and the uncertain identification of the presently studied epigean species, a hypothesis of sister-group relationship between Eigenmannia sp. and $E$. vicentespelaea lacks phylogenetic support. On the other hand, these are the only members of the Clade F of Eigenmanninae (sensu Albert \& Campos da Paz, 1998) found in the study area (Bichuette \& Trajano, 2003). Thus, the most parsimonious geographic hypothesis (to be tested in a phylogenetic framework), which would involve no local extinctions of other species closer to any of the two above mentioned, is that of a sister-group relationship between them.

Several authors advocate a correlation between the time of isolation in the subterranean habitat and the degree of reduction of eyes and pigmentation (classical troglomorphisms), with populations isolated for shorter times showing less reduced and/or variable eyes and pigmentation than those homogeneously anophthalmic and unpigmented (Wilkens, 1982, 1986; Trajano, 1995). According to this hypothesis, $E$. vicentespelaea may represent a boundary case, as result of quite a short time in isolation, in view of the high degree of variability observed, mainly in relation to the eyes size.

It is not possible to know whether the troglobitic species is completely or only partially isolated from epigean species, because the latter was found in the same large river basin as E. vicentespelaea (the Paranã river basin, a tributary of the Upper Tocantins), but not in the same microbasins. In addition, there are records of quite large (see below) and well-fed specimens of Eigenmannia sp. in subterranean reaches from the Angélica and São Mateus streams, indicating that this typically epigean species is able to survive for a long time in the hypogean environment. Thus, in theory these fishes could join the exclusively subterranean $E$. vicentespelaea if they would find their way to the São Vicente stream basin. Therefore, E. vicentespelaea may be either the result of allopatric or parapatric differentiation.

The larger body sizes recorded for the specimens of Eigenmannia sp. captured in subterranean stream reaches may be related to a lower pressure of predation in this environment (corroborated by the record of potential predators in the epigean Rio da Lapa - Brycon sp. - see Bichuette \& Trajano, 2003). This may be associated to a low interspecific competition in caves because it seems that food represented by prey living on the large amount of vegetal debris carried during floods into the studied caves is not limiting for these fishes in hypogean habitats (Bichuette, 2003). Therefore, cave specimens of Eigenmannia sp. have the opportunity to take food in rather abundance and live longer without being preyed upon, thus reaching larger sizes than the epigean ones.

The description of E. vicentespelaea was based on two specimens (Triques, 1996), preserved in alcohol since 1978, and its diagnosis was based solely on the OD:HL proportion. As expected, much wider variation in diagnostic characters and morphometric data was found when additional specimens 
were examined. Nevertheless, eyes size allied to pigmentation and body sizes may still be used to distinguish the two species of Eigenmannia from São Domingos karst area.

Examined material. Eigenmannia vicentespelaea: MZUSP 42605, holotype, 120 mm LEA; São Vicente II Cave: São Domingos County, Goiás State, Central Brazil. MZUSP 47984, paratype, 1 ex., $160 \mathrm{~mm}$ LEA; São Vicente II Cave: São Domingos County, Goiás State, Central Brazil. MZUSP 83461, 4 ex., 108.1-164.5 mm LEA; São Vicente I Cave: São Domingos County, Goiás State, Central Brazil. MZUSP 83462, 2 ex., 117.2 and 121.9 mm LEA; São Vicente II Cave: São Domingos County, Goiás State, Central Brazil. MZUSP 83463, 1 ex. (C\&S), 118.9 mm LEA; São Vicente II Cave: São Domingos County, Goiás State, Central Brazil. MZUSP 83464, 1 ex., 161.6 mm LEA; São Vicente II Cave: São Domingos County, Goiás State, Central Brazil. MZUSP 83465, 2 ex., 106.2 and 109.2 mm LEA; São Vicente II Cave: São Domingos County, Goiás State, Central Brazil. MZUSP 834666, 1 ex., 119.0 mm LEA; São Vicente II Cave: São Domingos County, Goiás State, Central Brazil. MZUSP 83467, 3 ex., 109.7123.3 mm LEA; São Vicente II Cave: São Domingos County, Goiás State, Central Brazil. MZUSP 83468, 3 ex., 81.6-116.2 mm LEA; São Vicente II Cave: São Domingos County, Goiás State, Central Brazil. MZUSP 83469, 1 ex., 112.1 mm LEA; São Vicente II Cave: São Domingos County, Goiás State, Central Brazil. MZUSP 83470, 3 ex., 72.5-97.7 mm LEA; São Vicente II Cave: São Domingos County, Goiás State, Central Brazil. MZUSP 83471, 1 ex. (C\&S), 106.7 mm LEA; São Vicente II Cave: São Domingos County, Goiás State, Central Brazil.

Eigenmannia sp.: MZUSP 83472, 3 ex., 52.6 and 71.8 mm LEA (one not measured); rio da Lapa: São Domingos County, Goiás State, Central Brazil. MZUSP 83473, 2 ex., 54.7 and 62.9 mm LEA; rio da Lapa: São Domingos County, Goiás State, Central Brazil. MZUSP 83474, 2 ex., 74.1 and 75.8 mm LEA; rio da Lapa: São Domingos County, Goiás State, Central Brazil. MZUSP 83475, 2 ex., 70.3 and 81.1 mm LEA; rio da Lapa: São Domingos County, Goiás State, Central Brazil. MZUSP 83476, 1 ex. (C\&S), 81.1 mm LEA; rio da Lapa: São Domingos County, Goiás State, Central Brazil. MZUSP 83477, 1 ex., 73.6 mm LEA; rio da Lapa: São Domingos County, Goiás State, Central Brazil. MZUSP 83478, 2 ex., 119.8 and 136.4 mm LEA; Angélica Cave: São Domingos County, Goiás State, Central Brazil. MZUSP 83479, 2 ex., 100.8 and 127.5 mm LEA; São Mateus III Cave: São Domingos County, Goiás State, Central Brazil.

\section{Acknowledgements}

We are greatly indebted to several colleagues and friends who helped us in the field, especially to Amazonas ChagasJr., Danilo Allegrini, Alberto Akama, Marcelo R. Britto, Flávio C. T. Lima, and the local guide and helpful assistant, Ramiro H. Santos. Thanks are also due to Ricardo Campos-da-Paz for the suggestions with regard to Eigenmannia species status. The Agência Ambiental de Goiás, for permission (\# 028/98) and to the Park Manager, Regina B. Schulz, for allowing the use of the Park facilities. This paper was benefited with the comments and criticism of two anonymous reviewers. IBAMA granted us permission for collections (license \# 02001.005646/ 98-40). Scholarship and financial support was given by Fundação de Amparo à Pesquisa do Estado de São Paulo (\# 98/13858-1). We are also grateful to the Departamento de
Zoologia - IBUSP, for support to develop this study. The junior author is partially supported by the Conselho Nacional de Desenvolvimento Científico e Tecnológico - CNPq (fellowship \# 306066/88-2).

\section{Literature cited}

Ab'Saber, A. N. 1977. Os domínios morfoclimáticos na América do Sul. Geomorfologia, 52: 1-21.

Albert, J. S. 2001. Species diversity and phylogenetic systematics of American knifefishes (Gymnotiformes, Teleostei). Miscellaneous Publications Museum of Zoology, University of Michigan, 190: $1-127$.

Albert, J. S. 2003. Sternopygidae. Pp. 487-491. In: Reis, R. E.; S. O. Kullander \& C. J. Ferraris (Eds.). Check List of the Freshwater Fishes of South and Central America. Edipucrs, Porto Alegre, $729 \mathrm{p}$.

Albert, J. S. \& R. Campos-da-Paz. 1998. Phylogenetic systematics of Gymnotiformes with diagnoses of 58 clades: A review of available data. Pp. 419-446. In: Malabarba, L.; R. E. Reis; R. P. Vari; Z. M. S. Lucena, \& C. A. S. Lucena (Eds). Phylogeny and Classification of Neotropical Fishes. Edipucrs, Porto Alegre, 603p.

Alves-Gomes, J. A.; G. Ortí; M. Haygood; A. Meyer, \& W. Heiligenberg. 1995. Phylogenetic analysis of the South American electric fishes (Order Gymnotiformes) and the evolution of their electrogenic system: a synthesis based on morphology, electrophysiology, and mitochondrial sequence data. Molecular Biology and Evolution, 12(2): 298-318.

Bichuette, M. E. 2003. Distribuição, biologia, ecologia populacional e comportamento de peixes subterrâneos, gêneros Ituglanis (Siluriformes: Trichomycteridae) e Eigenmannia (Gymnotiformes: Sternopygidae) da área cárstica de São Domingos, nordeste de Goiás. Unpublished Phd. Thesis, Universidade de São Paulo, São Paulo, 330p.

Bichuette, M. E. \& E. Trajano. 2003. Epigean and subterranean ichthyofauna from São Domingos karst area, upper Tocantins river basin, Central Brazil. Journal of Fish Biology, 63(5): 11001121.

Bullock, T. H.; N. Fernandes-Souza; W. Graf; W. Heiligenberg; G. Langner; D. L. Meyer; F. Pimentel-Souza; H. Scheich \& A. Viancour. 1979. Aspectos do órgão elétrico e eletrorrecepção nos Gymnotoidei e outros peixes amazônicos. Acta Amazonica, 9: 549-572.

Campos-da-Paz, R. 1997. Sistemática e taxonomia dos peixes elétricos das Bacias dos Rios Paraguai, Paraná e São Francisco, com notas sobre espécies presentes em rios costeiros do leste do Brasil (Teleostei: Ostariophysi: Gymnotiformes). Unpublished Ph. D. Thesis, Universidade de São Paulo, São Paulo, 336p.

Campos-da-Paz, R. 2000. On Sternarchorhynchus Castelnau: a South American electric knifefish, with descriptions of two new species (Ostariophysi: Gymnotiformes: Apteronotidae). Copeia, 2: 521535.

Christiansen, K.1962. Proposition pour la classifications des animaux cavernicoles. Spelunca, 2: 76-78.

Eigenmann, C. H. \& W. R. Allen. 1942. Fishes of western South America. University of Kentucky, Lexington. 494 pp.

Juberthie, C. 2000. The diversity of the karstic and pseudokarstic hypogean habitats in the world. Pp. 17-39. In: Wilkens, H.; Culver, D. C. \& W. F. Humphreys (Eds). Ecosystems of the World 30. Subterranean Ecosystems. Elsevier, Amsterdan, 791p.

Lundberg, J. G. \& F. Mago-Leccia. 1986. A review of Rhabdolichops 
(Gymnotiformes: Sternopygidae), a genus of South American freshwater fishes, with descriptions of four new species. Proceedings of the Academy of Natural Sciences of Philadelphia, 138(1): 53-85.

Mago-Leccia, F. 1978. Los peces de la familia Sternopygidae de Venezuela. Acta Cientifica Venezolana, 29 (supl. 1): 1-89.

Mago-Leccia, F. 1994. Electric fishes of the continental waters of America. Classification and catalogue of the electric fishes of the Order Gymnotiformes (Teleostei: Ostariophysi), with descriptions of new genera and species. Biblioteca de la Academia de Ciencias Fisicas, Matematicas y Naturales, Caracas, Venezuela, 29: 1- 225.

Nimer, E. 1979. Climatologia do Brasil. Supren, Rio de Janeiro, 421p.

Taylor, W. R. \& G. A. Van Dyke. 1985. Revised procedures for staining and clearing small fishes and other vertebrates for bone and cartilage study. Cybium, 9: 107-119.

Trajano, E. 1995. Evolution of tropical troglobites: Applicability of the model of Quaternary climatic fluctuations. Mémoires de Biospéologie, 22: 203-209.

Triques, M. L. 1996. Eigenmannia vicentespelaea, a new species of cave dwelling electrogenic Neotropical fish (Ostariophysi: Gymnotiformes: Sternopygidae). Revue Française de Aquariologie, 23(1-2): 1-4.

Wilkens, H. 1982. Regressive evolution and phylogenetic age: the history of colonization of freshwaters of Yucatan by fish and crustacea. Bulletin of the Texas Memorial Museum, 128: 237243.

Wilkens, H. 1986. The tempo of regressive evolution: studies of the eye reduction in stygobiont fishes and decapod crustaceans of the Gulf Coast and West Atlantic region. Stygologia, 2 (1/2): 131143.

Zar, J. H. 1996. Biostatistical analysis. Prentice-Hall International, New Jersey, 662p.

Received March 2005

Accepted September 2005 